\title{
Drama in L2 learning: A research synthesis
}

\author{
George Belliveau \& Won Kim
}

\begin{abstract}
This article closely examines research literature from the last two decades that focuses on the use of drama in L2 learning and teaching. L2 (second language) is used as an umbrella term that refers to any language learned in addition to one's first language. The authors review online teaching resources, position papers, scholarly articles and existing research findings on the impact of implementing drama in L2 learning that were published in English. This review of literature suggests that despite a wide-spread pedagogical interest and scholarly conviction in the possibilities of educational drama in creating a more contextuallysituated, engaging, multi-modal, and empowering L2 learning experience, there is still little empirical evidence concerning what is actually taking place in L2 classrooms and how students perceive and react to their learning experiences when drama is introduced. More systematic, long-term research studies are needed to deepen our understanding of the impact of using drama in L2 classrooms on a range of aspects of teaching and learning.
\end{abstract}

\section{Introduction on Drama for Learning}

Drama in the language classroom is ultimately indispensable because it offers a lens for learners to use their imagination. It draws upon students' abilities to imitate and express themselves and, if well handled, it should arouse interest and foster personality development. Drama encourages adaptability, fluency and communicative competence. It puts language into context and, by giving learners experience of success in real-life situations, it should arm them with the confidence for tackling the world outside the classroom (Davies 1990: 97).

Drama has been recognized for its pedagogical contributions to learning by a number of scholars in the fields of drama/theatre in education (Heathcote \& Bolton 1995; Wagner 1998; Neelands 2000; O'Connor 2010; Nicholson 2011; Anderson 2012), process drama, role drama and story drama (O'Toole 1992; O'Neill 1995; Bowell \& Heap 2001, 2005; Miller \& Saxton 2004; Booth 2005; Fels \& Belliveau 2008; Eriksson 2009) as well as drama and literacy (Grady 2000; Baldwin \& Fleming 2003). Using various drama-based approaches to teaching and learning, these scholars propose, to varying degrees, aesthetic, 
creative, imaginative, and educational experiences for participants. The mentioned authors (as well as others) offer insights as to how and why the application of drama fosters learning in multiple ways, in multiple contexts, and with multiple learners - including second language (L2) learners. L2 is used as an umbrella term that refers to any language learned in addition to one's first language. ${ }^{1}$

A sub-set of scholars have focused some of their thinking on ways that drama can support L2 learners (i.e., White 1984; Kao \& O'Neill 1998; Whiteson 1998; Stinson 2009; Stinson \& Winston 2011; Winston 2011). Their work points to ways that educational drama supports L2 learners develop expertise in a second language as they "actively imagine and process information through the use of language and other symbolic forms" (Baldwin \& Fleming 2003: 33). Most often students who participate in educational drama activities are invited to engage with a story, looking at the narrative and characters from multiple perspectives and interpretations, and then responding to the work in diverse and often interactive ways. These kinesthetic as well as cognitive and emotional educational experiences that drama often fosters are empowering to L2 classrooms (as well as other learning contexts). As such, a pedagogical and scholarly interest in the role of educational drama in L2 learning has evolved in tandem with pedagogical attempts towards more contextualized, communicative, and socially attuned L2 learning experiences.

To offer a critical perspective on the landscape of recent scholarship in drama and L2 learning, we closely reviewed and synthesized published scholarly work and research studies in English within the last 20 years. Our research synthesis, largely North American-based, along with some European studies, extends the work of two key studies that gathered research in areas closely related to educational drama: Deasy's Critical Links study (2002) looked at over 120 arts-based studies, of which 19 were in drama and its potential impact on learning; and Podlozny's (2000) meta-analysis about drama instruction and student verbal achievement which looked at 80 studies. Our survey looks at studies published until $2012^{2}$, as well as narrows the scope of Deasy and Podlozny's meta-analyses by specifically looking at drama and L2 studies. This article builds on the scholarly interest ignited by Stinson and Winston's 2011 special issue of Research in Drama Education where an insightful editorial essay along with seven key articles on the topic of drama and second language learning were gathered from international scholars.

In search of the published work, widely accessible sources of databases were utilized for this review: ERIC, HW Wilson, Google Scholar, and Linguistics and Language Behaviour Abstracts, along with the research published in this journal, SCENARIO. The search terms employed included 'second language' and 'drama.'

\footnotetext{
1 The term Foreign Language (FL) learning is often used in the literature, and we see it as a vital term within the umbrella of L2.

${ }^{2}$ Schewe (2013) has since published a scoping article that first takes a historical/critical look at the field, and then proposes new ways to consider foreign language teaching and learning that involves theatre.
} 
The initial search resulted in over 120 items including book chapters, published articles, unpublished dissertations, position papers, conference proceeding papers and on-line teacher resource sites. In the process of selection, the following criteria were applied: 1) time frame (i.e., since 1990); 2) accessibility (i.e., the availability of full text); and 3) relevance of topics (i.e., the use/role of drama in L2 learning). As a result, there were over 65 remaining items. Despite an effort to cover a wide range of the research literature, we recognize that this review is not exhaustive. Our search methodology has limitations in that we searched for publications in English, while recognizing insights provided by research literature in other languages on the topic (e.g., German, Austrian, French) that were not included in this review due to focusing our scope and word limit for this article. However, our central aim is to provide a critical survey of readily available scholarship in English of the recent two decades for educators who are interested in the possibilities and complexities of drama in L2 contexts. What follows is a synthesis of the literature grouped into teacher resources, position papers, empirically grounded studies and classroom-based case studies. The article closes by addressing research implications drawn from our critical review.

\section{Growing Interest in Drama in L2 Classrooms and Teacher Resources}

The use of educational drama has increasingly been of interest to teachers and practitioners, from primary to tertiary levels, in the field of second language learning and teaching. Such increasing interest is also evidenced by the emergence of new scholarly conferences (e.g., International Association of Performing Language), workshops within conferences (Conference of the German Association of Foreign Language Research, 2011), journals specific to the field of drama and L2 education (e.g., Scenario: Journal for Drama and Theatre in Foreign and Second Language Education, which commenced in 2007), the 2011 Research in Drama Education special issue mentioned earlier, and Winston's (2011) recent book of collected case studies in diverse teaching settings, Second Language Learning through Drama: Practical Techniques and Applications, have been important additions to the growing database of resources for L2 practitioners/educators/researchers utilizing drama.

Building on earlier resources of teaching L2 through drama (e.g., Maley \& Duff 1984; Smith 1984; Di Pietro 1987; Wessels 1987), the last two decades have witnessed a continuous proliferation of teaching resources (e.g., Wessels 1991; Whiteson 1998; Burke \& O'Sullivan 2002; Winston 2004, 2011) in response to a growing pedagogical interest to the questions of how to integrate drama into L2 learning. Whiteson's (1998) collection of practical dramatic activities and strategies as part of the New Way series published by TESOL (Teaching English to Speakers of Other Languages) has initiated over a decade's worth of growing interest in using drama in L2 classrooms, and this is evidenced by 
numerous online teacher resource websites. The following represent examples of available resource sites:

- Bringing Language Alive through Process Drama: SYLLABUS: http:// drama2010 evo . pbworks.com/f/Bringing+Language+Alive+through+Processt Drama+SYLIABUS . pdf. This is a 6-week, online workshop in process drama in ESL/EFL classrooms offered annually by Gary Carkin and Shin-Mei Kao in the TESOL-Drama Forum.

- My Album: http://gary-carkin.magix.net. Gary Carkin creates a site displaying a collection of video drama activities.

- Drama Education Network: www.dramaed.net. This is a commercial site that provides services, teaching resources, and products for schools and teachers to promote the use of drama in arts, literacy, and language education.

- Improv Encyclopedia: http://improvencyclopedia.org. This provides a resource for improvisational activities in classrooms.

- ESLFlowRole-Plays: http://www.eslflow.com/roleplaysdramatheatregames . html. This provides information and resources for using role-plays on a range of different topics and themes in ESL/EFL classrooms.

- Drama in the ESL Classroom: www.esldrama.weebly.com. This resource offers a collection of drama techniques, lesson plans, strategies, and further resources in the use of drama in ESL/EFL classrooms.

- Resources for Teaching Drama: https://www.msu.edu/ caplan/drama/ biblio.html. Sarah Dodson, drama educator, presents a useful resource for language and literacy teachers interested in incorporating drama into classrooms, including scholarly articles, books, lesson plans, and online sites.

\section{Limited Use of Drama in L2 Classrooms}

Despite a widespread interest in using drama by teachers who strive for more contextually situated, engaging, and communicative language use in the classroom, ironically drama does not seem to be widely implemented in language classrooms (Kao \& O'Neill 1998; Liu 2002; Even 2008; Dinapoli 2009), as transmission models of language learning remain prevalent in many educational contexts (Kramsch 1996; Wagner 1998; Paran 2006; Gilmore 2007; Cummings 2009, 2011). Even when integrated, the use of drama has often been limited to decontextualized scripted role-plays, memorization of superficial dialogues, and warm-up games that fall outside the curriculum (Dinapoli \& Algarra 2001; Dodson 2002; Marschke 2004; Matthias 2007). 
Importantly, Kao \& O'Neill distinguish process-oriented educational drama from a less contextualized and script-based drama by describing it as "drama activities that aim to go beyond short term teacher dominated exercises. Instead the drama is extended over time and it is built up from ideas, negotiations, and responses of all the participants in order to foster social, intellectual, and linguistic development" (1998: x). Though as noted earlier, such approaches to educational drama have not yet secured a meaningful place in L2 classrooms. However, a number of scholars share a conviction that drama can benefit in different aspects of $\mathrm{L} 2$ learning. The educational benefits found in the position papers are summarized in the following section.

\section{Synthesis of Position Papers: Benefits of Using Drama in L2 Classrooms}

\subsection{Promoting Intercultural Communicative Competence}

In L2 classrooms where language is treated in a decontextualized manner, students are seldom provided with opportunities to experience an essential part of actual spontaneous communication. As such, engagement with cooperative and dialogical learning experience is needed (Dinapoli \& Algarra 2001). Dinapoli and Algarra argue that, "learners need to be involved in discourse at a more personal level and the efficient and effective use of language in conversation" (2001: 3). With its learner-centered and multi-modal nature (Dodson 2000), drama can create an environment where L2 learners communicate with one another meaningfully and purposefully by means of verbal and non-verbal signs in a social context (Song 2000; Marschke 2004; Stinson \& Freebody 2006; Matthias 2007; Even 2011). Matthias states that dramatic activities invite L2 learners to experience language "as a system of communicative choices" (2007: 2) where they negotiate and exchange information and ideas in a make-believe setting. As such, drama-based L2 pedagogy facilitates opportunities for L2 learners to use language, experience it contextually, and develop their intercultural communicative competence (Byram 1997). Byram (1997) emphasizes that language learning involves developing one's intercultural communicative competence which encompasses elements such as open, curious, and critical attitudes, knowledge in sociocultural practices, skills of relating and making sense of cultures, abilities to discover and perform knowledge/attitudes/skills in and through interaction, and critical cultural awareness. In these processes of interaction, scholars suggest that drama pedagogy may be one of the optimal ways to foster and realize communicative language teaching (Song 2000; Cumico 2005; Even 2008).

During improvisational process-oriented drama, learners are engaged in numerous moments to understand and be understood by others (Boudreault 2010). Even during product-oriented scripted theatrical activities, growth in fluency in the target language occurs as learners experience the complex nature of authentic communicative aspects of language (i.e., hesitation, 
intonation, repetitions, incomplete sentences), as well as engage in rehearsals and performance, which calls for collaboration, negotiation, and meaning exchanges at personal and public levels among participants (Butt 1998; Burke \& O’Sullivan 2002; Fukushima \& Fujimoto 2009).

\subsection{Fostering Imagination}

L2 learners should not be viewed as passive information processors, but rather as astute "thinkers and language users" (Donaldson 1978: 121), inquirers (Fels \& Belliveau 2008), meaning-makers (Cox \& Boyd-Batstone 1997), capable experts (Heathcote \& Bolton 1995), or "active goal-oriented hypothesis-generating symbol manipulators" (Wagner 1998: 17). In this light, it is important that imagination and creativity be regarded as an integral part of the art of learning and teaching (Broom 2011). A number of scholars call for more attempts and efforts to be made to transform L2 classrooms to where imagination comes into play in the process of language learning through dramatic exploration (Liu 2002; Even 2008; Donnery 2009; Hristozoa 2009; Boudreault 2010). While allowing for ample opportunities to reflect on social, affective, and linguistic experiences in and through drama, a dramatic engagement with language and communicative situations can evoke learners' imagination to an extent where they may step out and move beyond the confined walls of the classroom.

\subsection{Facilitating Contextually-Situated Interaction}

In light that language and context cannot be separate and interaction plays a central role in language learning (Vygotsky 1978; Gibbons 2004; Johnson 2004; Atkinson 2011), another important benefit from using drama in L2 classrooms would be that drama can create an environment where language is presented, learned, and used in and through interaction situated in social contexts. Educational drama invites learners into contexts where they are encouraged to spontaneously interact with their environment in meaningful ways (Cumico 2005; Eun \& Lim 2009), experience different registers, styles, and discourses (Dodson 2000; Even 2011), and develop skills of discovery and interaction (Byram 1997), while collaboratively constructing imaginative worlds.

In addition to the benefits mentioned above, the following contributions of using a drama-based pedagogy in L2 learning are addressed in the position papers we reviewed: creating an environment for developing overall language and literacy skills in a holistic manner (Rieg \& Paquette 2009; Evatt 2010); enriching reading experiences with both literary and non-literary texts through a more intimate and deeper engagement with the texts (Even 2008; Boudreault 2010); connecting language, literature and culture (Cumico 2005; HoecherlAlden 2006); enhancing learners' confidence and motivation in learning and using language (Ralph 1997; Athiemoolam 2006; Aita 2009); fostering alternative ways of learning and knowing (i.e., embodied, performative, 
interdisciplinary, or kinesthetic inquiry) (Wagner 1998; Bas 2008; Donnery 2009; Even 2011).

\section{Synthesis of Empirical Studies on Drama and L2}

\subsection{Case Studies of Drama in L2 settings}

The majority of the literature we encountered for this review was either position papers or teacher resources, nonetheless, 30 empirical, data-driven, classroom-oriented research studies concerning drama in L2 education have been identified, most of which are descriptive case studies. Given that the studies were conducted in various second language contexts, the result of the review speaks to a widespread interest in using drama in L2 learning. What follows is a critical review and summary of a selection of these empirical research studies, followed by research implications drawn from this review. The descriptive research studies examined the integration of drama in various second language classrooms including, Italian (Ryan-Scheutz \& Colangelo 2004; Piazzoli 2011), Spanish (Wilburn 1992), German (Ronke 2005; Matthias 2007; Lauer 2008; Rothwell 2011), French (Dicks \& Le Blanc 2009; Early \& Yeung 2009; Giaitzis 2008; Ziltener 2011), and Arabic (El-Nady 2000).

\subsection{French classrooms}

Positive outcomes of drama on L2 development and L2 learning experiences were also witnessed in French classes for younger learners in Canada. One research project was an exploratory case study with a secondary French class where students created original picture book stories in French and then dramatized them for French-speaking children (Early \& Yeung 2009). Two separate descriptive case studies on the use of various drama activities with elementary core French students for the enhancement of motivation and L2 learning were respectively conducted by Giaitzis (2008) and Ziltener (2011). In addition, a survey-based research study in an elementary French as a second language class in Canada where participants engaged in a drama project on global simulations was undertaken by Dicks \& Le Blanc (2009).

\subsection{Italian classrooms}

Ryan-Scheutz and Colangelo (2004) undertook a case study to explore the feasibility of engaging in a full-scale theatre production for Italian learning. The eleven participants in the research were part of a 10-week Italian language workshop at the post-secondary level. In preparation for a theatre production that would take place at the end of a term, the participants were grouped into one of three roles: actors, designers or stage managers. Over the course of 27 rehearsals and the performance, participants became naturally engaged in various interactions and communicative tasks. During the process, not only 
actors but also stage managers and designers demonstrated linguistic growth because of a constant need for meaningful interactions among all participants for a common goal of performing the play on stage.

\subsection{German classrooms}

Similar findings were evident in German language classes. In Lauer's (2008) study, a group of advanced German learners at Georgetown University participated in the dramatization of a German novel. Lauer's observational data reveal that throughout the process of rehearsals and performances, the participants appeared to improve their language abilities while enjoying dramabased learning experiences. Matthias (2007) reports on another case study of German learners in an experimental three-week improvisational theatre workshop. This anecdote-based descriptive research study demonstrates how beginning German learners benefitted from using improvisational drama exercises and physical enactment (of a short story) that investigate intercultural foreign language situations. For her part, Ronke's (2005) thesis study found that the integration of drama in the German language classroom positively impacts language learning ranging from oral language competence, affective, cultural, and social learning.

\subsection{EFL classrooms}

Contributions of various dramatic approaches to L2 development are further evidenced in numerous English language learning contexts. For instance, Miccoli's (2003) case study explored the value of using drama to help $37 \mathrm{EFL}$ students develop their oral linguistic competence in a conversation-based class at a Brazilian university. Instead of a conventional transmission model of language learning, the class prepared for a theatrical production and during the process the students kept reflective journals to document their learning. Findings gained from student self-reports suggest that they experienced an improvement of oral skills, and an increased confidence in speaking in the target language. Miccoli explains that it was because drama created a purposeful and meaningful context where learners used language while jointly making cultural and linguistic analysis of their characters.

\subsection{Reader's Theatre}

In addition to engaging in theatrical productions, Readers Theatre (RT) was also found to be conducive to ESL development. Liu (2000) conducted an action research study with an intermediate ESL writing class in an American university to explore the possibilities of RT in L2 classrooms. Students in Liu's research were invited to share their favourite part of the reading, write responses to the RT, and create their own alternative ending to the story. Liu points out that, throughout these RT activities, "everyone was legitimate participants trying to contribute to the success of this creative reading" (2000: 357). Based on 
the analysis of data gathered through multiple sources such as researcher's and students' reflective journals, a survey on students' reactions to RT, and students writing assignments, Liu notes three key contributions that resulted from using RT within his language classroom: facilitated students' engagement with language; promoted peer collaborations; and created a positive class atmosphere.

\subsection{Playwriting}

Dramatic engagement using playwriting has also been found to benefit ESL learners. Elga (2002) addresses the efficacy of playwriting activities in English language development for her intermediate-level students within a Teaching English to Speakers of Other Languages (TESOL) program. In her action research project, she found that when students engaged in playwriting, rich opportunities for intensive language practice involving language skills were generated as well as a sense of ownership and accountability about their own playtexts, which in turn led to enhanced motivation.

\subsection{Intercultural Learning}

Along with linguistic benefits, drama-based learning also seems to have a positive effect on emotional aptitude or affective learning. Through an interpretive study with a Business university class using drama-based approaches, Dinapoli (2009) found that drama can promote adult L2 learners' broader and empathic understanding of underlying meanings of texts, because of the contextualized exposure to language, creativity, and emotional aspects of discourse. The study was however limited to the author's interpretation of only a few examples of students' oral/written presentations of their understanding of characters within plays. An analysis of more empirical data demonstrating a broader range of students' emotional engagement would strengthen the study.

Of a range of benefits of applying educational drama in L2 learning contexts, the role of drama in fostering a sense of intercultural understanding was explored in a number of qualitative case studies. In their separate descriptive studies, both Isbell (1999) and Donnery (2009) illustrate how the inclusion of improvised drama activities in the curriculum was conducive to the enhancement of crosscultural awareness of Japanese EFL college students through the description of student self-reports. Increased intercultural awareness was also witnessed by two researcher-teachers who taught content-based ESL classes using drama, Mcgowan-Rick (1994) and Dodson (2002). Mcgowan-Rick argues that his high school ESL students' experience of performing (versus only reading) Wilder's American classic Our Town enabled his class to not only learn about the content and themes within the play, but to also discover the emotions and journeys of the characters. The class participants, who were mostly newcomers to the United States, learned about American culture by performing it, and they readily related to, and identified with, the challenges faced by the characters 
within the play such as leaving home, love, and death. Dodson's (2002) study with university ESL students describes how her objectives of fostering intercultural understanding through the teaching of language were achieved through various engagements with theatre, and these included reading and discussing academic articles on theatre; reading plays; watching local live theatre performances and responding to them in writing; taking field trips to local theatres; engaging in various improvisational drama activities; and performing a play on stage. Based on their observation and students' own evaluation of their learning through drama, both Mcgowan-Rick and Dodson's descriptive documentations of their own classes illustrate how the growth of students' language competence and intercultural understanding can be fostered through drama-oriented L2 pedagogy. Similar findings were also witnessed in Bournot-Trites' et al. (2007) mixed-method study that compared the learning outcomes of two French immersion elementary classes engaged in a process drama about French Acadians in Canada. Both classes of similar socio-economic status studied the exact same content (Acadian culture), yet the control group used a traditional teacher-directed approach, whereas the experimental group used a drama-based pedagogical approach. The findings of the study based on triangulated data sources reveal that the experimental (drama) group demonstrated higher achievement in overall composition abilities in French, and a more positive attitude and higher motivation towards learning both language and content. The positive contribution made by dramabased pedagogy to students' increased intercultural understanding are further evidenced by a large-scale cross-cultural research project, carried out with approximately 5000 students in twelve European countries. This EU funded project makes use of mixed methods and provides empirical insights into how drama can foster personal development with high intercultural/social/civic communicative competence. The DICE research project (DICE 2010; Küppers 2011) offers a valuable contribution to the scholarly/pedagogical knowledge on the role of drama in intercultural competence with its close attention to measuring the impact of educational drama in L2 learning.

\subsection{Student interactions and talk}

Classroom interaction in the drama classroom has also received some scholarly attention as a topic of investigation. For instance, Kao \& O’Neill (1998) share their research on classroom discourse when educational drama is used within a Taiwanese university EFL classroom. Through a descriptive and quantitative investigation focused on student interactions, this systematic study provides insights as to how drama-based pedagogy can encourage participants to become more active language users while maintaining equal participation status. A similar study by Wilburn (1992) found that the nature of classroom discourse and teacher talk shifted significantly with his elementary Spanish immersion class when drama was used. Specifically, he found that, when educational drama was implemented, the students were naturally inclined to play a bigger 
role in participating and constructing classroom dialogue.

Other research studies looked into various L2 learning contexts to explore the learning potential of drama-based L2 instruction in enhancing linguistic awareness and increasing confidence and motivation in L2. These studies include an action research project with an EFL class in Taiwan using dramatic activities based on Shakespeare's work (Cheng \& Winston 2011); an experimental study on the effect of drama-based EFL instruction on English speaking abilities and attitudes of undergraduate students in Thailand (Janudom \& Wasanasomsithi 2009); a quantitative study on the positive effects of Arabic learners' vocabulary retention and higher engagement with language learning (El-Nady 2000); an action research study with immigrant/refuge adult ESL learners in an ESL class using Augusto Boal's theatre of the oppressed and involving critical pedagogy and performance (Louis 2002, 2005); the effects of drama on high school ESL learners' in the social studies content knowledge and English language proficiency (Nazare 2009); the use of dramatic activities based on a newspaper article on the topic of drug addiction in an English class at a South African university (Athiemoolam 2006); and a descriptive report of an advanced-level Japanese class at an American university working on a scripted theatre play (Fukushima \& Fujimoto 2009).

\subsection{Challenges and Benefits}

In addition to the positive impact of drama on L2 learning, it is important to note that there are pedagogical challenges and issues around the implementation of drama-based language instruction and these are discussed in some intervention studies (Gaudart 1990; Louis 2001; Stinson 2009; Piazzoli 2010). These studies speak to the challenges and issues to be taken into account when implementing drama-based L2 instruction (e.g., a need for teacher training; skepticism from teachers and students; product-driven or examination-oriented circumstances; cultural differences in learning styles among others).

To sum up, it seems evident from the case studies discussed above that positive outcomes and effects for L2 learners are taking place when dramabased interventions are applied. The integration of drama in L2 curriculum yield benefits for language learners in their language skills, intercultural understanding, attitudes to language learning and use, content learning, and connection to literature. Also, the studies suggest that significant pedagogical and research attempts have been made in a range of second language learning contexts to explore the affordance of drama-based L2 instruction.

Nevertheless, our review reveals that there is still a need for more empirical evidence in the literature on this topic. Literature available over the last two decades consists of few empirical studies that are systematic in methodology and their reporting of the analysis and findings. Despite the range of contributions on the topic, the majority of the studies reviewed in this paper are limited to being descriptive reports based mainly on personal anecdotes, observations, and intuitive interpretations of researchers. 


\section{Conclusion}

Our review of recent scholarly works suggests that drama-based L2 instruction is most often a welcomed approach in L2 classrooms for its range of benefits. Teaching resources, position papers and research studies affirm why and how the integration of drama into L2 classrooms can be advantageous: fostering communication competence, embodied and engaging learning, contextuallysituated interaction, confidence and motivation in learning and using language and deeper engagement with literature, to name a few. However, it seems imperative that more efforts be made by researchers and teachers to undertake systematic, long-term or longitudinal research in order to attain a fuller understanding of the possibilities, challenges, and complexities of second language learning through drama (Sam 1990; Wagner 1998; Paran 2006; Bournot-Trites et al. 2007; Gilmore 2007; Even 2008; Stinson \& Winston 2011).

A specific research recommendation that can be drawn from our review of the research literature is the need for classroom-based studies with a longitudinal component as well as data collected from various perspectives and sources. A more systematic investigation approach will help further our understanding of how learning takes place in L2 classrooms that use drama-based pedagogy, which includes the roles and values of classroom-based drama in various languages, with a range of students, and in a variety of learning contexts (Kao \& O'Neill 1998; Dodson 2000, 2002; Liu 2002; Winston 2004, 2011; Ronke 2005; Even 2008; Piazzoli 2011; Stinson \& Winston 2011). Another recommendation is to broaden the research context to include other sites. Most studies reviewed focused on younger learners (e.g., Wilburn 1992; Mcgowan-Rick 1994; Bournot-Trites et al. 2007; Dicks \& Le Blanc 2009; Early \& Yeung 2009; Ziltener 2011) or university classroom contexts (e.g., Kao \& O’Neill 1998; Miccoli 2003; Athiemoolam 2006; Donnery 2009; Janudom \& Wasanasomsithi 2009). It seems imperative to expand the literature to other educational settings. For instance, a large number of L2 learners participate in private language institute settings, where educators may include drama-based approaches. Most participants in these private schools are adult learners, usually unfamiliar with drama-based learning strategies as they typically come from educational contexts that favor linear, static transmission models of teaching (Sam 1990; Kao \& O’Neill 1998; Louis 2002, 2005; Dinapoli 2009).

There is also a need for more classroom-based empirical investigation that specifically focuses on the actual impact of educational drama on classroom interaction and students' $\mathrm{L} 2$ development. The important questions that Kao and O'Neill (1998) raised one and a half decades ago still need close investigation: How is the interaction in drama-based L2 classroom constructed/developed? What learning experiences and classroom interaction are promoted for L2 development? How do students' verbal/non-verbal practices develop over time in drama-based classroom? These questions can be addressed through a participant-oriented, emic, discourse-analytic lens (Antaki \& Widdicombe 
1998; Richards 2006) which can provide insights into what actually takes place in and through interaction in the classroom. Other approaches to address the questions raised above could include video-essays (Küppers 2012), ethnodrama (Saldana 2011) or research-based theatre (Belliveau \& Lea 2011; Wager et al. 2009) that allow a participant-oriented representation of data to illuminate dynamic, imaginative, multi-layered, bodily and performative dimensions of learning and interaction afforded by drama-based pedagogy.

A further research recommendation derived from this review surrounds the challenges a number of educators face when implementing drama-based pedagogies with learners mainly familiar with traditional, teacher-centered approaches. Witnessed by Stinson (2009), Liu (2002), Louis (2002), and Gaudart (1990), educators working with primarily students of Asian educational backgrounds face particular challenges. Student-centered dramabased approaches are often unfamiliar to these students, as their English learning has largely been confined to grammar and reading skills. In this light, an investigation into how students and teachers perceive and react to their learning/teaching experiences with drama-based pedagogy from their own perspectives could deepen our understanding of the pedagogical challenges.

Also, our understanding of what takes place in a drama-based language classroom can be further expanded through an investigation of identity (Norton 2000; Cumico 2005; Cummins 2009, 2011; Neelands 2004; Weber 2005). The interactions during drama-based language activities, along with students' perceptions and attitudes in relation to aesthetic and educational learning could be examined in light of literature on identity. Antaki and Widdicombe (1998) point out that identity is consequential and pivotal in social action and social order, as such a close analysis of identity work in and through interaction in drama-based classrooms may increase our understanding of how identity shapes the way interaction is developed and constructed, given that classroom interaction serves a critical role in creating an identity-empowering learning experience for L2 learners (Cummins 2009, 2011).

Booth stresses that, "a student's awareness of possible meanings and patterns is vital to that student's reception and production of language and the student derives this awareness from hearing and using language. . . Meanings are learned through one's total life experience" (2005: 93). In this regard, it is essential that L2 learners experience and experiment with multi-faceted meanings, forms, and modes of human communication systems as active participants, drawing on their previous experiences, knowledge and multiple, dynamic, socially-constructed identities. Drama-based L2 pedagogy may afford such learning opportunities. Cummins calls for collaborative efforts to make classrooms into "an interpersonal space within which the acquisition of knowledge and formation of identity is negotiated. Power is created and shared within this interpersonal space where minds and identities meet" (2009: 8). In such a space, L2 learners' voices can be empowered and grow in both a literal and a figurative sense (Cox \& Boyd-Batstone 1997). We suggest that educational drama has a role to play in contributing to create an empowering 
interpersonal educational space where diverse voices are in dynamic interaction with one another in multiple ways.

In drawing this paper to a close, we wish to share Leggo's thoughts on learning:

As a language educator, my commitment is simply, but irrevocably, to seek the anima, the spirit, the energy that is at the heart of all discourse. Poetry calls attention to itself as a rhetorical structure, as a discursive practice. Where prose is often perceived as a transparent window on reality, poetry is opaque. Poetry invites readers to slow down. Poetry invites us to listen. Poetry is a site for dwelling. . . A poem is a textual site where a diversity of languages, emotions, and perspectives can be entertained. (2004: 8-9)

Drama also promotes these rich, empowering poetic moments in which a wide range of language and other symbolic forms, perspectives, emotions, and interpretations can be purposefully mingled and entertained as students have opportunities to linguistically, aesthetically, and imaginatively engage in active interaction with one another. Nonetheless, as informed in this review, although many educators agree on the benefits of drama in L2 learning - enriching classroom interaction, learning experiences, language skills, and developing a sense of diversity, collaboration, creativity, and aesthetic imagination these factors have often been overlooked and under-investigated by teachers, researchers and policy makers. Further pedagogical and scholarly attention is needed to develop a deeper understanding on ways that educational drama within L2 settings can contribute to authentic, intercultural and embodied language/literacy learning.

\section{Bibliography}

Aita, Sean (2009): The Theatre in Language Learning (TILL) Model: Exploring Theatre as Pedagogy in the L2 Environment. In: SCENARIO 3/1, 70-89

Anderson, Michael (2012): MasterClass in Drama Education: Transforming Teaching and Learning. London: Continuum

Antaki, Charles; Widdicombe, Susan (1998): Identities in Talk. London: Sage

Athiemoolam, Logamurthie (2006): The Role of Drama-in-Education in the English Second Language Classroom. Paper presented at the $37^{\text {th }}$ Annual ELTAI conference, India, retrieved from http://webcache.googleusercontent.com/search?q=cache:P7Nfqx0iP1kJ:www.zsn.unioldenburg.d

Baldwin, Patrice; Fleming, Kate (2003): Teaching Literacy through Drama: Creative Approaches. London: Routledge/Falmer

Belliveau, George (2009). Elementary Students and Shakespeare: Inspiring Community and Learning. In: The International Journal of the Arts in Society $4 / 2,1-8$ 
Booth, David (2005): Story Drama: Creating Stories through Role playing, Improvising, and Reading Aloud. Markham, ON: Pembroke

Boudreault, Chris (2010): The Benefits of Using Drama in the ESL/EFL Classroom. In: The Internet TESOL Journal XVI/1, retrieved from http://iteslj.org/Articles/Boudreault-Drama.html (last accessed 21/09/2013)

Bournot-Trites, Monique; Belliveau, George; Spiliotopoulos, Valia; Seror, Jeremie (2007): The Role of Drama on Cultural Sensitivity, Motivation and Literacy in a Second Language Context. In: Journal for Learning through the Arts 3/1, 1-35

Bowell, Pamela; Heap, Brian S. (2001): Planning Process Drama. London: David Fulton

Burke, Ann; O'Sullivan, Julie C. (2002): Stage by Stage: A Handbook for Using Drama in the Second Language Classroom. Portsmouth, NH: Heinemann

Butt, Rex (1998): Improvisation and language acquisition: Actor training as a tool to enhance fluency. In: College ESL 8/2, 58-63

Byram, M. (1997). Teaching and assessing intercultural communicative competence. Clevedon, UK: Multilingual Matters

Cheng, Astrid; Winston, Joe (2011): Shakespeare as a Second Language: playfulness, Power and Pedagogy in the ESL Classroom. In: Research In Drama Education, The Journal of Applied Theatre \& Performance 16/4, 541-556

Cox, Carole; Boyd-Batstone, Paul (1997): Crossroads: Literature and Language in Culturally and Linguistically Diverse Classrooms. Upper Saddle River, NJ: Merrill

Cumico, Sonia (2005): Teaching Language and Intercultural Competence through Drama: Some Suggestions for a Neglected Resource. In: Language Learning Journal 31/1, 21-29

Cummins, Jim (2009): Transformative Multiliteracies Pedagogy: School-Based Strategies for Closing the Achievement Gap. In: Multiple Voices for Ethnically Diverse Exceptional Learners 11/2, 1-19

Cummins, Jim (2011): The Intersection of Cognitive and Sociocultural Factors in the Development of Reading Comprehension among Immigrant Students. In: Reading and Writing, retrieved from

http://www.springerlink.com/content/rm482640gtj06346/ (last accessed 21/09/2013)

Davies, Paul (1990): The Use of Drama in English Language Teaching. In: TESL Canada Journal, 8/1, 87-99

Deasy, Richard J. (ed.) (2002). Critical Links: Learning in the Arts and Student Academic and Social Development. Washington, D.C.: Council of Chief State School Officers

Di Pietro, Robert (1987): Strategic Interaction: Learning Languages through Scenarios. Cambridge: Cambridge University Press 
DICE Consortium (2010): The DICE has been cast. A DICE resource - Research findings and recommendations on educational theatre and drama. (Ed. Cziboly, Ádam.) Budapest, Hungary

Dicks, Joseph; Le Blanc, Barbara (2009): Using Drama for Learning to Foster Positive Attitudes and Increase Motivation: Global Simulation in French Second Language Classes. In: Journal for Learning through the Arts 5/1, retrieved from http://escholarship.org/uc/item/31745098

Dinapoli, Russell (2009): Using Dramatic Role-Play to Develop Emotional Aptitude. In: International Journal of English Studies 9/2, 97-110

Dinapoli, Russell; Algarra, Vicky (2001): Role-Plays as Strategically Active Scenarios. Paper presented at the Annual Congress of the Spanish Association of Applied Linguistics (19th, Leon, Spain, May 3-5, 2001)

Dodson, Sarah (2002): The Educational Potential of Drama for ESL. In: Bräuer, Gerd (ed.): Body and Language: Intercultural Learning through Drama. Westport, CT \& London: Ablex Publishing, 161-178

Dodson, Sarah (2000): FAQS: Learning Languages through Drama. In: TEXAS Papers in Foreign Language Education 5/1, 129-141

Donaldson, Margaret (1978): Children's Minds. London: Fontana

Donnery, Eucharia (2009): Testing the Waters: Drama in the Japanese University EFL Classroom. In: SCENARIO 3/1, 17-35

Early, Margaret; Yeung, Cindy (2009): Producing Multimodal Picture Books and Dramatic Performances in a Core French Classroom: An Exploratory Case Study. In: Canadian Modern Language Review 66/2, 299-322

Elgar, Ann Gillian (2002): Student Playwriting for Language Development. In: ELT Journal 56/1, 22-28

El-Nady, Mamdouh (2000): Drama as a Teaching Technique in the Second Language Classroom. In: Dialogue on Language Instruction 14/1-2, 41-48

Eriksson, Stig (2009): Distancing at Close Range: Investigating the Significance of Distancing in Drama Education. Norway: Abo

Eun, Barohny; Lim, Hye-Soon (2009): A Sociocultural View of Language Learning: The Importance of Meaning-Based Instruction. In: TESL Canada 27/1, 12-26

Evatt, Stephanie (2010): Drama in the English Language Learning Classroom: A Holistic Approach to Language Acquisition. In: Insight 2/1, 11-12

Even, Susanne (2008): Moving in(to) Imaginary Worlds: Drama Pedagogy for Foreign Language Teaching and Learning. In: Die

Unterrichtspraxis/Teaching German 41/2, 161-170

Even, Susanne (2011): Drama Grammar: Towards a Performative Postmethod Pedagogy. In: Language Learning Journal 39/3, 299-312

Fels, Lynn; Belliveau, George (2008): Exploring Curriculum: Performative Inquiry, Role Drama, and Learning. Vancouver, BC: Pacific Educational Press 
Fukushima, Yoshiko; Fujimoto, Junko (2009): Learning and Teaching Japanese Language through Drama. Paper presented at the $17^{\text {th }}$ Princeton Japanese Pedagogy Forum, retrieved from

http://webcache.googleusercontent.com/search?q=cache:nVDYfrxK5NQJ:www.princeton.edu/pjp (last accessed 21/09/2013)

Giaitzis, Luisa (2008): Using Dramatic Activity to Enhance Junior Core French Students' Motivation and Oral Communication Skills. Unpublished M.A. thesis, Brock University

Gilmore, Alex (2007): Authentic Materials and Authenticity in Foreign Language Learning. In: Language Teaching 40/2, 97-118

Gibbons, Pauline (2004): Changing the Roles Changing the Game: A Sociocultural Perspective on Second Language Learning in the Classroom. In: Williams, Geoff; Lukin, Annabelle (eds.): The Development of Language: Functional Perspectives on Species and Individuals. London and New York: Continuum Publishing, 196-216

Gorjian, Bahman; Moosavinia, Seyyed; Jabripour, Azadeh (2010): Dramatic Performance in Teaching Drama in EFL Contexts. In: TESL-EJ 13/4, retrieved from

http://www.tesl-ej.org/wordpress/issues/volume13/ej52/ej52a4/ (last accessed 21/09/13)

Grady, Sharon (2000): Drama and Diversity: A Pluralistic Perspective for Educational Drama. Portsmouth, NH: Heinemann

Gaudart, Hyacinth (1990): Using Drama Techniques in Language Teaching. Malaysia. (ERIC Document Reproduction Service No. ED 355 823)

Heathcote, Dorothy; Bolton, Gavin (1995): Drama for Learning: Dorothy Heathcote's Mantle of the Expert Approach to Education. Portsmouth, NH: Heinemann

Hester, Stephen; Eglin, Peter (eds.) (1997): Culture in Action: Studies in Membership Categorization Analysis. Washington DC: International Institute for Ethnomethodology and Conversation Analysis, University Press of America

Hoecherl-Alden, Gisela (2006): Connecting Language to Content: Second Language Literature Instruction at the Intermediate Level. In: Foreign Language Annals 39/2, 244-254

Isbell, Katharine (1999): Intercultural Awareness through Drama. In: Forum $37 / 1$, retrieved from http://eca.state.gov/forum/vols/vo137/no1/p10.htm

Janudom, Ratchadaporn; Wasanasomsithi, Punchalee (2009): Drama and Questioning techniques: Powerful Tools for the Enhancement of Students' Speaking Abilities and Positive Attitudes towards EFL Learning. In: ESP World 5/26, Volume 8, 1-19

Johnson, Marysia (2004): A Philosophy of Second Language Acquisition. New Haven: Yale University Press 
Kao, Shin-Mei; O'Neill, Cecily (1998): Words into Worlds: Learning a Second Language through Process Drama. Stamford, CT: Ablex Publishing

Kramsch, Claire (1996): Proficiency Plus: The Next Step. (ERIC Digest No. 4) Eugene, OR: ERIC Clearinghouse on Educational Management (ERIC Document Reproduction Service No. ED402789)

Küppers, Almut (2012): Cultural learning through drama tasks: An action research approach. In: SCENARIO 6/1, 127-133

Küppers, Almut (2011): The DICE Consortium (2010): The Dice has been cast. In: SCENARIO 5/1, 107-112

Lauer, Mark (2008): The Performing Arts in Second Language Acquisition: A Report on the Experience of Dramatizing a Novel. In: SCENARIO 2/1, 18-40

Leggo, Carl (2004): Living Poetry: Five Ruminations. In: Language \& Literacy $6 / 2,1-14$

Liu, Jun (2000): The Power of Reader's Theatre: From Reading to Writing. In: ELT CT \& London: Ablex Publishing, 51-70

Louis, Ross McKeehen (2002): Critical Performative Language Pedagogy: Augusto Boal's Theatre of the Oppressed in the English as a Second Language Classroom. Unpublished $\mathrm{PhD}$ dissertation, Louisiana State University

Louis, Ross McKeehen (2005): Performing English and Performing Bodies: A Case for Critical Performative Language Pedagogy. In: Text and Performance Quarterly 25/4, 334-354

Maley, Alan; Duff, Alan (1982): Drama Techniques in Language Learning: A Resource Book of Communication Activities for Language Teachers ( $2^{\text {nd }}$ ed.). Cambridge: Cambridge University Press

Marschke, Renee (2005): Creating Contexts, Characters and Communication: Foreign Language Teaching and Process Drama. Unpublished M.A. thesis. Centre for Innovation in Education

Matthias, Bettina (2007): Show, Don't Tell: Improvisational Theatre and the Beginning Foreign Language Curriculum. In: SCENARIO 1/1, 56-69

Maxwell, Matt (1999): Music and Drama in Second Language Acquisition: Essential Components of a Holistic Approach. In: Mosaic 6/2, 10-16

Mcgowan-Rick, Molly (1994): Our Town: Drama as Curriculum. In: MINNETESOL Journal 1/12, 31-47

McRae, John (1985): Using Drama in the Classroom. Oxford: Pergamon Press

Miccoli, Laura (2003): English through Drama for Oral Skills Development. In: ELT Journal 57/2, 122-129

Miller, Carole; Saxton, Juliana (2004): Into the Story: Language in Action through Drama. Portsmouth, NH: Heinemann

Nazare, Nicole (2009): Using Role Play to Increase the Understanding of Social Studies Content for English-Language Learners. Unpublished M.A. thesis, Caldwell College 
Neelands, Jonothan (2000): Structuring Drama Work: A Handbook of Available Forms in Theatre and Drama. New York: Cambridge University Press

Nicholson, Helen (2011): Theatre, Education and Performance: The Map and the Story. Basingstoke, UK: Palgrave Macmillan

Norton, Bonny (2000): Identity and Language Learning: Gender, Ethnicity and Educational Change. Harlow, England: Longman/Pearson Education

O'Connor, Peter (ed.) (2010): Creating Democratic Citizenship through Drama Education: Selected Writings of Jonothan Neelands. Stoke on Trent: Trentham Books

O'Toole, John (1992): The Process of Drama: Negotiating Art and Meaning. New York: Routledge

O'Neill, Cecily (1995): Drama Worlds: A Framework for Process Drama. Portsmouth, NH: Heinemann

Paran, Amos (2006): Literature in Language Teaching and Learning. Case Studies in TESOL Practice Series. Alexandria, VA: Teachers of English to Speakers of Other Languages, Inc.

Piazzoli, Erika (2011): Process Drama: the Use of Affective Space to Reduce Language Anxiety in the Additional Language Learning Classroom. In: Research in Drama Education: The Journal of Applied Theatre and Performance 16/4, 557-573

Podlozny, Ann (2000): Strengthening Verbal Skills through the Use of Classroom Drama: A Clear Link. In: Journal of Aesthetic Education 34/3-4, 239-276

Ralph, Edwin (1997): The Power of Using Drama in the Teaching of Second Languages: Some Recollections. In: McGill Journal of Education 32, 273-288

Richards, Keith (2006): 'Being the Teacher': Identity and Classroom Conversation. In: Applied Linguistics 27/1, 51 -77

Rieg, Sue; Paquette, Kelli (2009): Using Drama and Movement to Enhance English Language Learners' Literacy Development. In: Journal of Instructional Psychology 36/2, 148-154

Ronke, Astrid (2005): Drama and Theatre as a Method for Foreign Language Teaching and Learning in Higher Education in the United States. Unpublished PhD dissertation, Technische Universität Berlin, Germany

Rothwell, Julia (2011): Bodies and Language: Process Drama and Intercultural Language Learning in a Beginner Language Classroom. In: Research in Drama Education: The Journal of Applied Theatre and Performance 16/4, 575-594

Ryan-Scheutz, Colleen; Colangelo, Laura (2004): Full-Scale Theatre Production and Foreign Language Learning. In: Foreign Language Annals $37 / 3,374-389$

Saldaña, Johnny (2011): Ethnotheatre: Research from page to stage. Walnut Creek, CA: Left Coast Press 
Sam, Wan (1990): Drama in Teaching English as a Second Language: A Communicative Approach. In: The English Teacher 9, 1-11

Schewe, Manfred (2013): Taking Stock and Looking Ahead: Drama Pedagogy as a Gateway to a Performative Teaching and Learning Culture. In: SCENARIO 7/1, 5-27

Smith, Stephen (1984): The Theater Arts and the Teaching of Second Language. Reading, MA: Addison-Wesley

Song, Hyunok (2000): Teaching English through Drama. In: Journal of Pan-Pacific Association of Applied Linguistics 4/2, 298-305

Stinson, Madonna (2009): Drama is like Reversing Everything: Intervention Research as Teacher Professional Development. In: Research in Drama Education 14/2, 225-243

Stinson, Madonna; Freebody, Kelly (2006): The DOL Project: The Contributions of Process Drama to Improved Results in English Oral Communication. In: Youth Theatre Journal 201, 27-41

Stinson, Madonna; Winston, Joe (eds.) (2011): Special issue. Drama and Second Language Learning. In: Research In Drama Education, The Journal of Applied Theatre \& Performance 16/4, 479-488

Ulas, Abdulhak Halim (2008): Effects of Creative Educational Drama on Developing Oral Skills in Primary School Children. In: American Journal of Applied Sciences 5/7, 876-880

Vygotsky, Lev (1978): Mind in Society. Cambridge, MA: Harvard University Press

Wager, Amanda; Belliveau, George; Beck, Jamie; Lea, Graham (2009): Exploring Drama as an Additional Language through Research-based Theatre. In: SCENARIO 3/2, 50-66

Wagner, Betty Jane (1998): Educational Drama and Language Arts: What Research Shows. Portsmouth, NH: Heinemann

Weber, Susanne (2005). Intercultural learning as identity negotiation. Frankfurt am Main: Peter Lang

Wessels, Charlyn (1987): Drama (Resource Books for Teachers). Oxford: Oxford University Press

Wessels, Charlyn (1991): From Improvisation to Publication on an English through Drama Course. In: ELT Journal 45/3, 230-236

White, John (1984): Drama, Communicative Competence and Language Teaching: An Overview. In: The Canadian Modern Language Review 40/4, 595-599

Whiteson, Valerie (1998): New Ways of Using Drama and Literature in Language Teaching. Washington D.C.: New Ways in TESOL (Series II: Innovative Classroom Techniques)

Wilburn, Deborah (1992): Learning through Drama in the Immersion Classroom. In: Bernhardt, Elizabeth (ed.): Life in language immersion classrooms. Philadelphia: Multilingual Matters 86, 67-83 
Winston, Joe (2004): Drama and English at the Heart of the Curriculum. London: David Fulton

Winston, Joe (2011): Second Language Learning through Drama: Practical Techniques and Applications. London: Routledge

Ziltener, Eva (2011): Playing with Possibilities: Drama in the Elementary Core French Classroom. Unpublished M.A. thesis, University of British Columbia, Vancouver, Canada

Belliveau, George; Lea, Graham W. (2011): Research-based Theatre in Education. In: Schonmann, Shifra (ed.): Key Concepts in Theatre Drama Education. Rotterdam: Sense Publishers, 332-338 